\title{
The applicability of some marketing principles to the Gospel
}

\author{
I.D. Wolfaardt \\ Business and Marketing Consultant \\ POTCHEFSTROOM
}

\author{
G.J. de Klerk \\ Department of Business Economics \\ Potchefstroom University for $\mathrm{CHE}$ \\ POTCHEFSTROOM
}

\begin{abstract}
The primary objective of this study was to test the applicability of some marketing principles to the Gospel. The secondary objective was to ascertain a correlation between the growing and declining churches and their respective adherence to or rejection of marketing principles.

A new concept of marketing - the stewardship marketing concept - had to he formulated to satisfy the unique character of the Gospel. This broadened stewardship marketing concept allow's the Gospel to be described as an intangihle product which can be promoted, distribuled and exchanged for scarce resenurces.

Man's inahility to 'sell' an excellent product like the Gospel clcarly asks for a new distribution system to promote the Gospel. This new distribution system, defined as a multi-channel vertical marketing system, can supplement and does not necessarily become a substitute for existing church structures.
\end{abstract}

\section{Objectives of the study}

The Church, event the dynamic Church, needs some additional measures to render it more effective in the environment of the 1990's. Since the science of marketing plays such a critical role in the success of modern business it was decided to enter into a study to test the applicability of some marketing principles to the Gospel.

Based on census information released by the Central Statistical Service of the Republic of South Africa for 1926, 1951 and 1980, trends in church membership were analysed. The Methodist and Presbyterian denominations represented the English mainline churches. The N.G. Kerk, N.H. Kerk and the Gereformeerde Kerke represented the Afrikaans mainline churches while the Pentecostal/ Charismatic churches were represented by the Apostolic Faith Mission/Apostoliese 

Evangelie Kerk van God and Assemblies of God.

From this analysis it was evident that the Pentecostal/Charismatic groups are growing, the English mainline denominations are stagnant while the Afrikaans mainline denominations are declining.

The primary objective of the research was to test the possibility that some modern marketing principles may be applicable in the proclaiming of the Gospel.

The secondary objective of the study was to ascertain the possibility that the growing group is more open to, and indeed is using some marketing principles in one way or another, that the declining group is the least inclined to using marketing principles, and that the stagnated group lies somewhere between these two extremes

\section{Method of research}

The encumbrances of the Church (manifested by the visible decline in membership and the Church's impotence to influence society at large) referred to above, only appear to be the actual problems. Spiritual discernment recognises these failures to be merely the manifestations of the core problem.

Informal inquiries, perusal of assorted publications, observations, and personal experience have led to the conclusion that the deficiences suffered by the Church were not due to the debasement of the product, or the introduction of competitive products - the two most common reasons for organisational default (Wolfaardt, 1992:130). These findings necessitated an empirical research

The most obvious route of examining external secondary sources was followed a procedure which resulted in the analysis of the census figures

After having perused the contents of internal secondary sources (public and private), it was concluded that this method would not really satisfy the demand for an elucidation of the identified core problem, and that a primary research project was called for.

Since 'marketing problems' is a very expansive term, a plethora of pertinent facts were listed which had to be reduced into a practical questionnaire. Van Doren and Smith (1985:14) designed a self-analysis for non-profit organisations, gauging their marketing acumen. It was consequently decided to use their experience after considerable adaptions to the contents of their original questionnaire. The questionnaire which was used in this empirical study comprised twenty questions of which one was open ended, six were simple dichotomous, and thirteen were ranking questions on a sixpoint Likert scale. The questions were divided into 
four divisions designed to diagnose the Churcl's marketing acumen in terms of orientation, research, planning and control.

The composition of the population necessitated a sample design which would accommodate the characteristic structure of the Church. Therefore each of the methods of stratified random sampling, cluster sampling and systematic sampling contributed to arriving at a conclusion. A sample size of 250 was regarded as both practical and reliable enough to yield the necessary accuracy. Initially respondents were contacted by post, some of whom had to be followed up by personal or telephonic interviews. Eventually a total response rate of $56 \%$ was recorded.

\section{The stewardship marketing concept}

Since the late 1950's the inarketing concept has started to exert its influence on the unsophisticated consumer, who was not ready to deal with new phenomena brought about by powerful marketing instruments. Characteristic of this period of time was that the average consumer, by and large, had no awareness of what it required to be a discriminating shopper. Millar (1963:4) states that the consumers were obsequious to shopkeepers, overindulgent to manufacturers and, all too often, merely symbols to be manipulated at will by advertising agencies.

The exploitation of consumers and their counter actions through various activist organisations, the abuse of the profit motive, and the exploited environment are indicative that the marketing concept, in spite of its superior efficiency to other philosophies of marketing, and in spite of the fact that it is not fully applicable to the Gospel, is in any event not an appropriate concept for the Gospel. The reason is that a concept that can be so readily distorted, must have inherent weaknesses which could equally misconstrue the mission of the Church.

Because of the growing concern of the general public regarding these matters, the social marketing concept found its existence. In spite of marketing thought having reached its pinnacle in the adoption of the social marketing concept, it still is an objectionable concept. In essence it remains the profit motive, which is the only driving force for such marketing activities, albeit tempered by an expression of social responsibility of some kind. The judgement is not against the motive for profit - but against profit being the only or dominant driving force.

Even the social marketing concept, although tempered by humanistic ideals, is still not the appropriate concept for the Gospel since it is intrinsically still amenable to the failings of man-made philosophy.

Although some philosophies of marketing were found to be partially applicable, none were worthy of the Gospel. All the existing marketing philosophies are pro- 
duct or consumer orientated and rely on a man-made product which can be adapted at will to suit whichever human (producer or consumer) desire. The Gospel is, in its core, a given, perfect and unalterable product. As such it needs a marketing philosophy which will carry its benefits and sacrifices to a market which will benefit from it.

A new concept of marketing - the stewardship marketing concept - thus had to be formulated. Man is appointed by God to be a steward of the earth and its resources and of one another with an ultimate responsibility to his Creator. People should be served by satisfying their (responsible) needs and wants in such an effective, and efficient way that the realised profit will be able to sustain the company, and guarantee its continuation.

Stewardship marketing must discover what underlying need man is desirous of for fulfilment, and fulfil it by a way becoming of a steward. It is therefore not the Gospel which must be subjected to change in order to be adapted to the desires of the market, but the stewardship marketing concept, being sensitive to the real need of people, presenting the Gospel in the most effective manner

It is this philosophy guiding the stewardship marketing concept which has been used as a yardstick to measure the applicability of some marketing principles to the Gospel.

Is it possible, however, to embrace all exchange relationships with the science of marketing, regardless of what the exchange comprises? This seems to be a possibility as confirmed by Novelli (1989:15) who states that successful nonprofit marketing has helped to increase public acceptance of disabled persons, has discouraged pregnant women from smoking, las prevented forest fires, has fought drug abuse, has curbed the spread of Aids, and has even encouraged people to eat more fruit.

Because of this broadened marketing philosophy it seems to be an equally valid deduction that the stewardship marketing concept could be applied to the Gospel. This deduction has little value if the Church, the instrument God uses to proclaim the Gospel, does not qualify for marketing management as well, and this test was therefore the next critical one

\section{Is the principle of market segmentation applicable to the Gospel?}

All the segmentation methods applied to the Gospel were found to be measurable, accessible and actionable (Wolfaardt, 1992:44-50). This means that, potentially, the Gospel can be as effectively marketed through target marketing as any other product, in spite of the structural unattractiveness of most of the segments the 
Church would operate in. It has been indicated as well (see Wolfaardt, 1992:5558) that the Church could, and should, position (and re-position) herself against her many competitors so as to clearly distinguish the product it offers (the Gospel), from the other relatively inferior products on the inarket. Since light dispels darkness the Cluurch could also reposition its competitors, especially though the tools of promotion.

With conventional market segmentation, consumer characteristics and behaviour have been analysed in detail to identify profitable segments. However, since brands vary widely in their perceived characteristics, marketers should find merit in focusing on the consumer's perception of these characteristics as well. It was established that there is a firm relationship between a product and its brand (Cravens, 1991:391-397). In some cases branding is so strong that it becomes the product in the mind of the consumer. An example of this phenomenon is where the brand name adopts the generic name for the product. The same phenomenon can be applied to the Gospel. Religious people, meaning people who (most probably) were raised by parents who regularly attended church, and who are still perpetuating the habit of going to church, tend to judge all spiritual things consistent with their (brand) experiences of the past and present.

Rothberg (1976:223-234), with the concept of beyond market segmentation, has indicated that people discriminate among the various brands in a market according to their perceptions of the brand's real or imagined characteristics, and then choose brands whose characteristics they prefer - a preferance which is in accordance with their own personality.

That explains why the true Church can comprise a variety of denominations and congregations with the same product (the Gospel), but each with a different brand innage, and each attracting people according to their unique perception of the brand characteristics. With this concept of beyond market segmentation there is no need for the different denominations within the true Church to be in strife at all. From this disposition the research for the study has been conducted.

\section{Is the Gospel a product?}

The Gospel can be identified by the same ingredients Kotler (1988:446-447) uses for secular products.

* The core product: The core of what the Gospel offers to man is spiritual fulfilment. Benefits of spiritual fulfilment must be offered, and not merely the features of the Gospel. The marketer of the Gospel knows that when the benefits of this product are experienced it will be more fulfilling than any other substitute. Peace with God and man, for example, will obviate the use of liquor, drugs or status symbols. When applying marketing principles to 
The applicability of some marketing principles to the Gospel

the Gospel, it is possible to translate the core product into a tangible product.

* The tangible product: The tangible product can be identified by four typical characteristics:

- Quality denotes the competence (spiritual and organisational) with which the Gospel is presented, through various services, by people of diverse ministries.

- Features represent the practical value of the Gospel in everyday circumstances. Services and fellowship in various forms, including home gatherings and visitations, are examples.

- Style concens the unique manner of branding, managing the evidence, and packaging the environment each intermediary (could be a congregation) displays.

- Brand name: Everything the Church does is branded. The congregation's name (affiliation) is the brand name by which it (the Church) is identified.

The augmentation of the Gospel is found in the emotional (fellowship) and material (welfare) activities of the Church. Congregations succeeding in customising their augmented product instead of standardising it, will (like any other business enterprise) experience exceptional growth, because of the much needed and appreciated individual recognition that accompanies this policy. This is nothing other than taking a sincere, loving interest in a fellow human being.

Since the Gospel, as a product, lends itself to product support systems the marketplace can experience the promised benefits and satisfactions. The Church can manage a pre-sale service strategy (where the service must be tangibilised and the evidence sincerely managed), and a post-sale service strategy. The most important aspects of a post-sale service strategy deals with after sales anxiety, repair services, training services and maintenance service, which the Church is quite capable of. Once a prospect becomes a client, a relationship is established which embodies a certain amount of equity. This equity must be enhanced lest the delicate relationship becomes jeopardised by competitors or disillusionment. There are a number of ways in which the Church can enlsance the equity even through systemisation and industrialisation (which is an area to explore in further studies).

Since the characteristics ordinarily inherent in tangible products compare well with those possessed by the Gospel, it would seem that the premise put forward by Fine $(1981: 22)$ is substantiated that an idea can serve as a substitute for see- 
mingly unrelated tangible products. That is why the Gospel is a substitute for any product and therefore in a broad sense every product is in competition with the Gospel, rendering idolating a common practice today as in ancient times.

\section{Can the Gospel be exchanged for scarce resources?}

In its simplest forn marketing can be described as the exchange of tangibles and intangibles. This definition presupposes discernible value, and at least two parties for a transaction to take place. If an exchange has not been transacted there could have been no marketing. These were the criteria, in terms of price, which would qualify the Gospel for marketability.

Price is what a consumer must sacrifice (give up) in order to obtain the benefits being offered. Money, however, is only the monetary element of price. Fine (1981:84-86) has, for instance, indentified four non-monetary ingredients of price. Examples of non-monetary price, particularly relevant to the Church, include sacrifices like time, effort, love, power, prestige, pride, friendship, family relationships, abstention, and adaption of a different life style. A close look at these various elements of non-monetary prices seems to justify the tern social price.

It has been proven (see Wolfaardt, 1992:84-97), through the concept of social cost, that all the price and value activities involving the Gospel relate to marketing actions, and even marketing terminology like value, cost, price, pay, sacrifice and buy are well used theological terminology, as found in the Bible.

Since an industry is made up of close substitutes it follows that these substitutes have a high cross-elasticity of demand, explaining why, if one product rises in cost, the demand for the other will rise. This is true for the Church (industry of religion) as well. If the social cost of the Gospel in a particular congregation rises, the demand for other congregations will increase. The findings of this research (Wolfaardt, 1992) seem to allude to the supposition that a substantial part of new members gained by one growing church can be due to brand switching from other less dynamic churches instead of the Kingdom of God being expanded.

In selecting the pricing method it is acknowledged that there is a cost element (crucifixion of the self), which is fixed (fixed cost), but the variable cost (social cost), and the impact of quality (the meeting of needs), are valuable elements of pricing to enhance the total value. Value can be enhanced by cost control, waste control and quality control through responsibility accounting (Rayburn, 1979:7).

Conversion is a (najor) purchase decision, and typically, the need arises to evaluate the expenditure. This post-purchase behaviour can (and should) be pro- 
The applicability of some marketing principles to the Gospel

perly managed since it will have a direct influence on repeat purchase behaviour, brand loyalty, and post-purchase equilibrium.

The Gospel is in fact being priced by the Church, whether the Church knows it or not, and all the pricing tools and strategies are available, and must be managed by the Church.

\section{Is the potency of promotion tools applicable to the Gospel?}

Van der Schroeff (1965:10-11), who could not have been influenced by the more recent development of concept marketing, stated in 1965 that the value of an asset is based on two factors:

* the utility it represents/exudes/releases to the owner,

* and the sacrifices which will be encountered/demanded to replace it with a substitute.

Here in short (even defined in cost accounting terms), is defined the importance of promotion to the Gospel. Through promotion the target market must be informed (communicated to) what utility God has created for mankind, and through promotion the target market must be informed what will have to be sacrificed should the Gospel be substituted for any other product (satisfier of needs). The individual must know and recognise what benefits a product (the Gospel) will offer him in order to want it, and he must also know what loss he will suffer if he goes without it. He must also know the negative characteristics of a product which will prevent him from wanting it. This statement summarises the role promotion strategy can play in the marketing of the Gospel.

The negative power in the art of communication was recorded by Clark (1988: 260 ), in his recount of how Smirnoff vodka was promoted to be the desired drink of the sixties and seventies within a juvenile consumer public.

On the positive side, it would seem that, from whatever angle promotion is viewed, the Gospel can be, and should be promoted by the same business and marketing principles as any other product.

\section{Conclusive findings of the empirical research}

Because of changing perceptions and wants, to name but two volatile elements in society, it is inconceivable that any organisation can be lethargic in the midst of relentless activity. The dynamic environment thrusts a life cycle on any product, brand or organisation, whether the affected recognises it or not. This means the Church is subject to the same life cycle concept as described by Dalrymple and Parsons (1982:356-359). According to these authors an introductory phase is 
followed by various stadia of growth ending in decline, with the eventual demise of the product.

Jesus introduced the Church and because of acceptance, the Church entered into a dynamic growth phase for the first two hundred years culminating in almost the whole known world being converted to Christianity (see Cerullo, 1979:60). A long period of maturity, with a 'cycle-recycle pattern' followed (this pattern was due to major revivals that took place). Some churches are now in a serious declining stage (see paragraph one), some have become obsolete and have disappeared already, and some are on their way to demise for the very same reasons products become extinct (see Towns et al., 1983:173-184). A church can become stale, changing her characteristic function to become inactive (dead), neither experiencing nor discharging the vibrant life of Jesus Christ, and in the process becomes part of the false church - which can perish as has been conclusively proven by the demise of churches in the post World War II in Europe. (See Towns et al., (1983:13), Burger, (1990:3); also Rev. 2:5.)

The object of this empirical research was to establish whether the successes or failures denominations experience in their growth, indicated by their status on the Product Life Cycle (PLC) curve, correlate with their level of marketing proficiency. Since there was a remarkable difference in growth figures between the different strata, it was premised that some inferences should be possible.

Experience taught Van Doren and Smith (see paragraph 2) that a non-profit organisation with a total of between 80-100 is 'marketing smart', a score of $60-79$ suggests good marketing sense, while a total of 40-59 indicates a weak awareness of marketing, but any lower count calls into question the organisation's ability to survive

Based on the research described in paragraph 2 it was established that Stratum C was the only stratum with a high frequency $(58,5 \%)$ in the categories 'marketing smart/good marketing sense', and it was the only stratum which finds itself in the growth phase of the PLC curve. Stratum B with a high frequency $(55,6 \%)$ in the category 'weak marketing sense' finds itself in the maturity stage of the PLC curve. Stratum A finds itself in the decaying maturity stage of the PLC curve, which correlates with her high frequency $(48,8 \%)$ in the 'threatened' category. A direct relation between applying marketing principles and growth (or lack of it) has been proven. 
The applicability of some marketing principles to the Gospel

\section{Table One}

Relationship between the application of marketing principles and growth

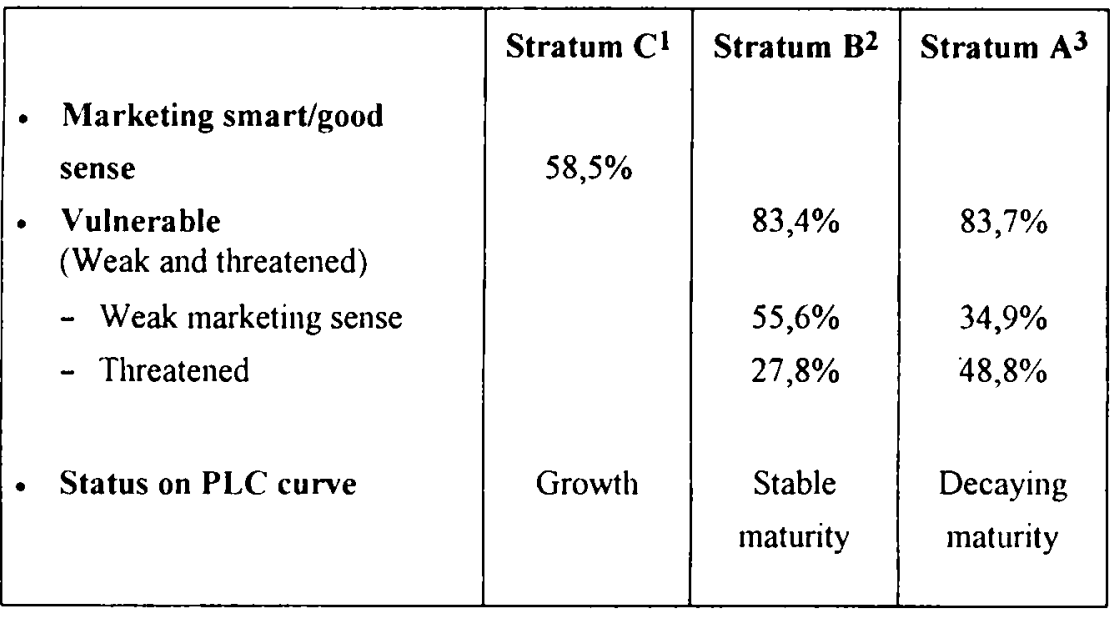

Whereas the three different strata were specifically tested for their marketing aptitude, and whereas the results are summarised in Table One, it is logical to deduce that one of the reasons for stratum C's superior growth performance must be her acumen to employ some marketing principles contrary to stratum B which displays a low marketing disposition, and stratum A which divulge a very low marketing disposition. The secondary objective of the study undertaken has been attained by this substantiation of the supposition.

Although some marketing principles have been found to be applicable to the Gospel, strata A, B and C has each in its own way (revealed by the analysis of the questionnaire) demonstrated the serious lack of the Church to employ these principles to the benefit of the Kingdom of God. Since the deficiency vests in the Clurch (people, and not God), and the Clurch is part of the distribution system,

1 Stratum C comprises the Apostolic Faith Mission and International Fellowship of Christian Churches (being the Pentecostal and Charismatic Churches respectively).

2 Stratum B comprises the Methodist and Presbyterian Church

3 Stratum A comprises the N.G. Hervormde and Gereformecrde Kerk 
distribution system which must be corrected and therefore the distribution system needs special attention.

\section{A suggested distribution policy for the Gospel}

\subsection{Multi-channel marketing systems}

The denominational Church is used to an exclusive distribution system where each congregation has its own territorial rights. This is common business practice and protects the profitability of the retailer, but can also encourage staleness. Another common business practice is selective distribution and its application is found in the hierarchy of the International Fellowship of Christian Churches (IFCC). This fellowship comprises almost all the independent Charismatic churches founded after 1980. They carefully select and test an applicant before approval to affiliation is given.

There is merit in both systems, except that, standing alone, it does not allow for intensive distribution, which, in the case of the Gospel, does not militate against exclusive, or selective distribution methods. In proposing a new distribution policy for the Gospel, there is no need for substitution - only for supplementation. The Church can err by seeing itself as a strictly facility-dependent service with a heavy reliance on capital intensive fixed assets, sited at convenient points around the community. However, the Church is in the fortunate position to perform its services independent of fixed structures of mortar and brick, to be also a facilityindependent service. Its services are deliverable and can therefore be separated from the facility. Therefore electronic and print media as well as a host of other channels for example crusades, street and/or house to house/office to office and numerous kinds of person to person outreaches (by means of personal encounters, telephonic contacts or direct mail) to name but a few examples, can be employed simultaneously - devices which would therefore constitute a multi-channel marketing system.

\subsection{The administered vertical marketing system - a new approach for the Church to manage sophisticated marketing techniques}

Traditionally this marketing system is recognised by the coordination of successive stages of distribution and origination through the significant role of one of the parties in the system. Thus, a joint venture under the leadership of any of these participants boost their individual turnover by promoting a common cause. None of these parties experiences any conflict of interests as all of them build their respective kingdoms. 
This suggested relationship for the Church keeps existing hierarchies intact since it does not depend on ownership or on an agreement, but on leadership - stemming from expertise, financial, and administrative resources through able facilitators.

\subsection{A new channel strategy for the Church}

The proposed strategy is primarily based on three principles underpinning this new channel stratagem:

* The 'pull through' principle.

* The multi-channel marketing system.

* The administered vertical marketing system.

Such a strategy is based on a facilitator which should develop a coordinated multi-marketing strategy for the Gospel. Since no individual channel-member is qualified (in terms of training, financial, or administrative resources) to take on the role of leader, a new qualified, and non-sectarian channel-leader must be created who can, on behalf of all the cooperating churches, build an awareness of the Gospel (pull through principle) for intensive distribution through a multichannel marketing system.

This strategy can be described as a multi-channel administered vertical marketing system.

\section{Conclusion}

* The stewardship marketing concept fully applies to the Gospel.

* The creation of an assortment of utilities can be facilitated by effective market segmentation.

* The Gospel can be regarded as an intangible product which can be marketed through concept marketing.

* The Gospel can be transacted; it has a price, and therefore an exchangeable value, which can be enhanced through cost, quality, and waste control by means of responsibility accounting.

* Advertising, personal selling, sales promotion, publicity, and reseller support - the five major tools in promotion - are applicable to the Gospel.

* The Gospel is disseminated to people through a variety of internediaries the distribution systems which form the distribution structure unique to the Church. 
* A facilitator and a chanmel-leader, with respectively specialised knowledge and substantial financial/administrative resources, are needed to apply the proposed multi-marketing strategy.

\section{Bibliography}

BURGER, I. 1990. Die Kerk in die dekade van die negentigs. Pinksterboodskapper, 15(2):24, Februarie

CERULlO, M. 1979. Proof Producers. San Diego, California: World Evangelism, Inc. $195 \mathrm{p}$.

CLARK, E. 1988. The Want Makers. 1st ed. London: Guild Publishing. $416 \mathrm{p}$

CRAVENS, D.W. 1991. Strategic Marketing. 3rd ed. Homewood, Illinois : Richard D. Irvin, Inv. $833 \mathrm{p}$

DALRYMPLE, D.J. \& PARSONS, L.J. 1982. Marketing Management: Strategy and Cases. 3rd ed. New York: John Wiley \& Sons. 821 p.

FINE, S.H. 1981. The Marketing of Ideas and Social Issues. 1st ed. New York, N.Y.: Preager Publishers. $227 \mathrm{p}$

KOTLER, P. 1988. Marketing Management: Analysis, Planning, Implementation and Control. 6th ed. Englewood Cliffs, New Jersey: Prentice-Hall, Inc. $776 \mathrm{p}$

MILLAR, R. 1963. The Affluent Sheep: A Profile of the British Consumer. 1st ed. London Longmans, Green and Co Ltd. $203 \mathrm{p}$.

NOVELLI, W. 1989. Nonprofit Seminar Focuses on Benefits of Longterm Marketing. Marketing New's, 23:5, Aug. 14

RAYBURN, G.R. 1979. Principles of Cost Accounting with Managerial Applications. Homewood, Illinois : Richard D. Irvin, lnc. $838 \mathrm{p}$

ROTHBERG, R.R. 1976. Corporate Strategy and Product Innovation. New York : Macmillan. $518 p$

TOWNS, E.L., VAUGHAN, J.N. \& SEIFERT, D.J. 1983. The Complete Book of Church Growth. 4th. ed. Wheaton, Illinois: Tyndale House Publishers, Inc. $396 \mathrm{p}$

VAN DER SCHROEFF, H.J. 1965. Kosten en kostprijs. Zesde druk. Kosmos, Amsterdam N.V. Uitgeversmaatschappij. $586 \mathrm{p}$

VAN DOREN, D.C. \& SMITH, L.W. 1985. Self-Analysis Can Gauge Marketing Orientation Marketing New's, 19:15, December 6.

WOLFAARDT, I.D. 1992. The Applicability of Some Marketing Principles to the Gospel Potchefstroom : PUCHE. (Dissertation M.Com.) $186 \mathrm{p}$ 
